\title{
Learning from past mistakes about nuclear waste
}

\author{
Any managing organization must be seen to be independent, transparent and legitimate.
}

Sir - Your News in Brief "Britain urged to dump nuclear-waste agencies" (Nature $417,111 ; 2002)$, reporting the Royal Society's call for reform of the institutions overseeing nuclear waste to restore public confidence in them, is consistent with the position of Nirex (the UK radioactive waste management agency), that the government should set up a new radioactive waste management organization independent from the nuclear industry. This is contained within the Nirex submission to the UK Department for Environment, Food and Rural Affairs consultation, which can be found on our website at www.nirex.co.uk.
Nirex has undergone its own reform to learn the lessons from past failures and ensure that, in future, whatever organization is responsible for managing nuclear waste in the United Kingdom, it is independent, transparent and above all legitimate in the eyes of the public.

Nirex was last in the public eye during the planning proposal in 1997 to build a 'rock-characterization facility' to examine suitability of the Sellafield site in northwest England for an underground nuclearwaste repository. The whole process was a resounding failure, for which Nirex accepts a significant part of the blame.

Since then, Nirex has done much work to try to learn from this: establishing an independent transparency panel; introducing a whistleblowers' policy; and holding regular dialogue with environmental groups. Stakeholders have generally welcomed these initiatives, which need to be built on in the future. An independent report by the consultancy Environmental Resources Management on stakeholder attitudes is on the Nirex website.

If people wish to find out more or become more actively involved, I would urge them to contact me at Nirex.

Chris Murray

Nirex, Curie Avenue, Harwell,

Oxfordshire OX11 ORH, UK

\section{To sell science, find out what people want to buy}

Sir - Elizabeth Tait in Correspondence (Nature 417, 221; 2002) discusses ways in which scientists and science communicators can work together. I would like to add that the current political pressure on scientists to become more marketoriented is making them reposition themselves and learn about research marketing. To this end, science communicators are supposed to make the public aware of the value that basic science contributes to society.

But are these activities 'research marketing'? In his famous essay "Marketing myopia" (Harvard Business Review 38, 465-56; 1960), Theodore Levitt argued that an industry's primary aim should be to satisfy customers, not to sell goods. This proposition should hold especially true for a service industry and basic science is ultimately no more than that.

Scientists can learn from Levitt to serve the needs of their customers, the public. According to Levitt, the difference between selling and marketing is that the former fulfils the needs of the seller and the latter the needs of the buyer. Academic scientists must stop trying to sell their achievements to the public, and instead market them by considering public needs right at the beginning of their endeavours.

However, scientists work on the not-quite-yet-possible, whereas public discussions of ethics and politics take place only when scientific results are just becoming possible. Hence there will be always a gap between scientific advances and societies' judgements about them. If scientists want to contribute to society, and also see the application of the knowledge they generate, they need to be less concerned with the 'public understanding of science' and more with scientists' understanding of the public.

To this end, market forces can contribute significantly to the understanding of what the public expects and desires from science. Therefore, scientists conducting basic science should expand their agreements, collaborations and partnerships with industrial sponsors and learn from them. Commercial companies can provide academic scientists not just with money, but with knowledge of what the market or, better, the public wants. Market forces will help to establish how much the public is willing to pay for advances in knowledge and technology. Till C. Jelitto

PR\&D - Public Relations for Research and

Development, Margaretenstr. 70, A1050,

Vienna, Austria

\section{Macroecology: new, or biogeography revisited?}

Sir - According to his News and Views report $^{1}$ of a recent symposium, Sean Nee and the British Ecological Society believe that macroecology is an infant discipline, a child of the conjunction of ecology and evolution. Yet the scope of macroecology is largely contained within the relatively old discipline of biogeography, which dates back at least to Alexander von Humboldt in the early nineteenth century. Some of the symposium's participants have written books about biogeography (see, for example, refs 2, 3). As Nee states, the difference between ecology and macroecology is largely a matter of scale, both in time and space. The bigger picture is, effectively,

biogeography.

Howard J. Fisher

Department of Geography, Avondale College,

Cooranbong, New South Wales 2265, Australia

1. Nee, S. Nature 417, 229-230 (2002).

2. Brown, J. H. and Lomolino, M. V. Biogeography 2 nd ed. (Sinauer, Sunderland, Massachusetts, 1998).

3. Whittaker, R. J. Island Biogeography (Oxford Univ. Press, Oxford, 1998).

\section{Online database could end taxonomic anarchy}

Sir — In his Commentary "Challenges for taxonomy”, H. C. J. Godfray ${ }^{1}$ presents compelling arguments for centralizing and revitalizing taxonomy using an Internet database of all taxon names and their descriptions, integrated with other biologically relevant information. $\mathrm{He}$ reasonably proposes that such a mammoth project would need to be undertaken in manageable stages, for example one group at a time. However, he does not suggest any logical starting points.

One obvious group is bacteria. The Bacteriological Code ${ }^{2}$ already centralizes bacterial taxonomy by ensuring that all name changes are either published in the International Journal of Systematic and Evolutionary Microbiology (IJSEM) or, if published elsewhere, are validated by announcement in that journal. Hence Godfray's innovative vision of what could be called a 'species bank' could be realized quite easily for bacteria by 
compiling a database of all current bacterial names, and integrating it with an online version of IJSEM to incorporate ongoing revisions. Given the importance of bacterial taxonomy in fields within and outside biology, such a database would be extensively accessed by 'pure' science, medicine and industry, and might thus be able to attract broad logistical support. Life began as bacteria, and it might be fitting if our comprehensive inventory of life also began with this group.

Although Godfray is correct to say that that current taxonomic codes prohibit "purely electronic description", the current version of the Zoological Code officially recognizes new names posted on websites as long as five hard copies are deposited in libraries ${ }^{3}$. However, such technophilia has permitted taxonomic anarchy. The ease of electronic publishing has encouraged some individuals to name electronically a plethora of dubious new species, in groups on which they have little taxonomic expertise (I do not cite these websites here, to avoid drawing further attention to them). The resultant mess will take decades to clear up. A central official taxonomic database, peer-reviewed and managed along the lines suggested by Godfray or by other means to this end, would solve this problem, facilitating rapid information dissemination via the Internet while at the same time filtering out unscrupulous taxonomic practices.

Michael S. Y. Lee

Department of Environmental Biology,

University of Adelaide, North Terrace,

Adelaide 5000, Australia

1. Godfray, H. C. J. Nature 417, 17-19 (2002.).

2. Sneath, P. H. A. International Code of Nomenclature of Bacteria (International Union of Microbiological Sciences, Washington DC, 1992).

3. International Commission on Zoological Nomenclature. International Code of Zoological Nomenclature, 4th edition (The International Trust for Zoological Nomenclature, London, 1999).

\section{Science's policy on access to private data}

Sir - In their thoughtful and welcome Commentary on data access "The times they are a-changin'" (Nature 417, 589-590; 2002), Ari Patrinos and Dan Drell make two statements about Science's publication policy that require correction.

With respect to the arrangement that allowed Celera Genomics to provide its sequence data through its own website, Patrinos and Drell say that the company limited free access to one million base pairs per day. In fact, Celera announced on its website that it would provide, and it did provide, compact discs containing the entire sequence to those who asked.

Patrinos and Drell also say that "those in the private sector have to negotiate a fee as a prerequisite for access". That is simply wrong - commercial accessors could and did receive the sequence free on executing a material transfer agreement that committed them not to distribute it or to use it for new research projects. That arrangement, incidentally, followed criticisms from members of the publicly funded Human Genome Project that any arrangement that required commercial accessors to pay would constitute "discriminatory licensing". The agreement we at Science reached with Celera circumvented that objection, thus meeting the challenge aptly described by Patrinos and Drell: "to suggest how the private sector can be persuaded to share more data, to the benefit of all". Donald Kennedy

Editor-in-Chief, Science, 1200 New York Avenue NW, Washington DC 20005, USA.

\section{Curiosity and generosity of a great scientist}

Sir — I read with sadness about the passing of Victor Weisskopf (Nature 417, 396; 2002). Twelve years ago, in San Juan, Puerto Rico, I was sitting next to an empty seat on a plane, wondering which of the many oversized people with too much carry-on baggage I would have to put up with for the flight to Boston. An elderly man sat down next to me and we began chatting: it was Weisskopf.

For five glorious hours I - who as a teenager had wanted to be an astronomer before I realized that my mathematical abilities were woefully inadequate to the task — plied Weisskopf with questions about physics and cosmology. In his turn, he posed penetrating questions about my own field of large-whale biology.

Weisskopf had all the hallmarks of a great scientist. He was ungrudgingly generous with his own vast knowledge and happy to share his insights with an interested stranger; and he was insatiably curious about everything in the world around him, whether or not relevant to his own work.

The unique and fortunate nature of my experience that day was not lost on me. After all, how often does one get the opportunity to ask one's seatmate, "So, do you think that general relativity and quantum theory will be unified in the foreseeable future?" and have the expectation of an informed reply?

The answer, by the way, was "No". Phillip J. Clapham

Large Whale Biology Program, Northeast Fisheries Science Center, 166 Water Street, Woods Hole,

Massachusetts 02543, USA

\section{Health supercourse to end Arab isolation}

Sir - Your news feature "Blooms in the Desert” (Nature 416, 120-122; 2002) focused on chinks of light against a gloomy backdrop of poor or nonexistent science funding. We, writing on behalf of the Islamic Global Health Network (islamicprevention.homestead.com), believe the critical element is the need to build Arabic scientific human capital, by building communities of Arab scientists.

Funding is important of course, but improving science training is more so, to unlock creativity and innovation. We in the field of epidemiology are in the process of making this real through the establishment of a global informationsharing Arab network, a model that can easily be followed for other scientific disciplines. The Internet is growing fast in Arab countries, so this can be used for collaborating and training, conserving scarce resources.

We are in the process of developing an Arabic 'Supercourse' of free-access PowerPoint lectures for instructors (www.pitt.edu/ super1/ighn.htm) as part of our global supercourse project, now consisting of more than 700 qualitycontrolled lectures from 118 countries (see Nature Med. 6, 358, 2000). We are translating the Supercourse lectures into Arabic and providing special, continuously updated lectures precisely describing health issues in various Arab countries. So far, 130 Arab scientists are collaborating to translate, share lectures and build an Arabic scientific Supercourse.

Through Supercourse, we are trying to raise the quality of research and teaching in Arab institutions, ending the isolation of Arab scientists through greater Internet interaction with non-Arab countries. We want to bring brilliant young people from Arab countries into science, both locally and globally.

Abdullatif Husseini, Rania Saad, Ronald E. LaPorte

Disease Monitoring and Telecommunications, WHO Collaborating Center, and Graduate School of Public Health, University of Pittsburgh, Pittsburgh, Pennsylvania 15261, USA 